\title{
Comparison of Smoking Habits and Coffee Consumption In Adolescents Against Hemoglobin Levels In Mojoroto Kediri City
}

\section{Perbandingan \\ Kebiasaan \\ Merokok \\ dan \\ Mengkonsumsi Kopi Pada Remaja Terhadap Kadar Hemoglobin Di Mojoroto Kota Kediri}

Mely Purnadianti ${ }^{\star}$ Nita Ermawati, Rere Nadhif Berlian

Teknologi Laboratorium Medis, Fakultas Sains, Teknologi \& Analisis, Institut Ilmu Kesehatan Bhakti Wiyata Kediri, Jl. KH Wachid Hasyim No.65, Bandar Lor, Kec. Mojoroto, Kediri, 64114, Jawa Timur, Indonesia

Cigarettes are processed tobacco using or without addictive substances. The increasing of hemoglobin in smokers due to the content of carbon monoxide causes hemolysis of erythrocytes that is stronger than oxygen, so that hemoglobin increases. In addition to smoking, the society's habit is about coffee consumption. Coffee is a beverage with high polyphenols. The decreasing of hemoglobin occurs when drinking too much coffee. It will reduce the absorption of iron and erythrocytes ability to deliver oxygen from the lungs to all tissues in the body, therefore the hemoglobin will decrease. One of the laboratory tests that is used to see hemoglobin levels in smokers and coffee consumers is the POCT method of hemoglobin examination. The purpose of this study was to analyze the comparison of the effect between smoking and coffee consumption on hemoglobin levels in adolescents on the streets of Mejenan Gang 3 Mojoroto Kediri. The method that is used in this research is comparative study and the sampling technique that is used purposive sampling with a sample size of 40 respondents. The results show that 10 adolescents (50\%) had abnormal hemoglobin levels and 10 adolescents (50\%) had normal hemoglobin levels. 5 teenagers (25\%) had abnormal hemoglobin levels and $15(75 \%)$ normal hemoglobin levels. Based on statistical tests, the results obtain pvalue 0.423 and $>0.05$. So it can be concluded that there is a moderate effect between cigarettes and coffee on hemoglobin levels in adolescents on Mejenan Street Gang 3 Mojoroto Kediri.

Keywords: cigarettes, coffee, hemoglobin, POCT

Rokok merupakan olahan tembakau dengan menggunakan bahan atau tanpa bahan tambahan. Peningkatan hemoglobin perokok karena kandungan karbonmonoksida menyebabkan hemolisis eritrosit yang lebih kuat dari oksigen sehingga hemoglobin meningkat. Selain rokok kebiasaan masyarakat yaitu konsumsi kopi. Kopi merupa- 
kan minuman dengan polifenol yang tinggi. Penurunan hemoglobin kopi terjadi ketika konsumsi berlebih, mengurangi absopsi $F e$ dan eritrosit dalam tubuh dan tidak mampu menghantarkan oksigen dari paru-paru ke seluruh jaringan sehingga hemoglobin menurun. Salah satu pemeriksaan laboratorium yang digunakan untuk melihat kadar hemoglobin pada perokok dan pengkonsumsi kopi yaitu pemeriksaan hemoglobin metode POCT. Tujuan penelitian ini untuk menganalisis perbandingan pengaruh rokok dan kopi dengan kadar hemoglobin pada remaja dijalan mejenan gang 3 mojoroto Kediri. Metode penelitian ini menggunakan Comparative Study dan teknik sampling yang digunakan adalah purposive sampling dengan jumlah sampel 40 responden. Hasil penelitian perokok diperoleh kadar hemoglobin tidak normal sebanyak 10 remaja (50\%) dan kadar hemoglobin normal sebanyak 10 remaja (50\%). Pada pengkonsumsi kopi diperoleh kadar hemoglobin tidak normal sebanyak 5 remaja (25\%) dan kadar hemoglobin normal sebanyak 15 remaja (75\%). Berdasarkan uji statistik didapatkan hasil nilai $\mathrm{p}$-value 0,423 dan $>0,05$ Sehingga disimpulkan terdapat pengaruh sedang antara rokok dan kopi terhadap kadar hemoglobin pada remaja di jalan Mejenan gang 3 Mojoroto Kediri.

Kata Kunci: hemoglobin, kopi, POCT, rokok 


\section{PENDAHULUAN}

Pada tahun 2008 jumlah perokok di dunia mencapi 1,3 milyar orang. Prevalensi perokok di Indonesia dari tahun ke tahun mengalami peningkatan. Menurut data hasil Riset Kesehatan Dasar, prevalensi merokok pada usia 5-9 tahun sebesar 1,2\%, pada usia 10-14 tahun sebesar 10,3\%, pada usia 15-19 tahun sebesar $33,1 \%$, pada usia $20-24$ tahun sebesar $12,1 \%$, pada usia 24-29 tahun sebesar 3,4\%, dan pada usia $\geq 30$ tahun sebesar 4\% Riskesdas (2007).

Derajat merokok berdasarkan Indeks Brinkman ditentukan oleh lama merokok dan rerata jumlah rokok yang dikomsumsi perhari. Menurut Leifert, lama paparan karbon monoksida dan jumlah rokok yang dihisap perhari dapat mempengaruhi kadar hemoglobin. Pada seseorang yang merokok 40 batang atau lebih perhari memiliki kadar hemoglobin $0,7 \mathrm{gr} / \mathrm{dl}$ lebih tinggi dibanding dengan orang yang tidak merokok Leifert (2008).

Hemoglobin $(\mathrm{Hb})$ adalah suatu senyawa protein dengan $\mathrm{Fe}$ yang disebut juga conjugated protein. Rangka $\mathrm{Fe}$ terdiri dari dua yaitu protoporphyrin dan globin (tetraphyrin). Protoporphyrin yaitu suatu turunan dari porfirin. Ini adalah senyawa organik yang memiliki struktur rumit yang memiliki warna yang dalam karena penyerapan radiasi elektromagnetik dalam jangkauan yang terlihat. Selain itu, senyawa ini tidak larut dalam air alkali. Globin yaitu zat protein dalam darah yang dipecah dan menjadi asam amino. Hemoglobin yaitu molekul eritrosit dengan fungsi mengangkut $\mathrm{O}_{2}$ Hoffbrand et al. (2012).

Kualitas darah ditentukan oleh Hemoglobin. Fungsi angkut $\mathrm{O}_{2}$ dari paru-paru ke jaringan tubuh dan membawa $\mathrm{CO}_{2}$ kembali ke paru-paru dari jaringan tubuh. Sel darah merah (eritrosit) membawa hemoglobin dalam sirkulasi. Sel ini berbentuk lempeng bikonkaf dan dibentuk di sumsum tulang. Pada manusia, sel ini berada dalam sirkulasi selama kurang lebih 120 hari. Konsentrasi Hemoglobin untuk menentukan perkembangan penyakit. Invasif guna uji Hemoglobin, sampling seorang pasien dan selanjutnya dilakukan analisis kadar hemoglobin Hoffbrand et al. (2012).

Peningkatan ini terjadi karena reflek dari mekanisme kompensasi tubuh terhadap rendahnya kadar oksigen yang berikatan dengan hemoglobin akibat digeser oleh karbon monoksida yang mempunyai afinitas terhadap hemoglobin yang lebih kuat, sehingga tubuh akan meningkatkan proses hematopoiesis lalu meningkatkan produksi hemoglobin akibat dari rendahnya tekanan persial oksigen di dalam tubuh Murray et al. (2014).

Selain peningkatan pada perokok di Indonesia juga mengalamipeningkatan pada konsumsi kopi setiap tahunnya. Menurut Hurlock, konsumsi kopi di Indonesia mengalami peningkatan setiap tahunnya. Hal inilah yang membuat tren peminum kopi terus meningkat Ajiwibawani (2015).
Kopi merupakan salah satu minuman yang banyak dikonsumsi oleh penduduk dunia. Menurut International Coffee Organization (ICO), sebanyak 9,7 juta ton kopi dikonsumsi di seluruh dunia pada 2017/2018. Angka tersebut menunjukkan peningkatan dari tahun-tahun sebelumnya yaitu 9,48 juta ton pada 2016/2017, 9,32 juta ton pada 2015/2016, dan 9,09 juta ton pada 2014/2015. Dari data tersebut dapat dilihat bahwa tingkat konsumsi kopi dunia terus meningkat dari tahun ke tahun WHO (2016).

Pengaruh kopi pada hemoglobin dapat menghambat penyerapan makanan yang mengandung besi karena adanya kadungan tanin dan pitat. Maka dari itu Fe akan berkurang dan menyebabkan jumlah hemoglobin dan sel darah merah menurun Ajiwibawani (2015).

Beberapa penelitian tentang hubungan atau perbandingan sel darah merah pada kadar hemoglobin dengan konsumsi kopi dengan kandungan kafein pada kopi dapat memberi efek samping salah satunya adalah gangguan tidur yang dapat menyebabkan kadar hemoglobin menurun sehingga dapat mempengaruhi kelainan pada bentuk sel darah merah. Penyebabnya yaitu karena kandungan kafein inilah yang membuat tetap bisa terjaga Apinino (2014). Dari penjabaran latar belakang tersebut menjadikan peneliti tertarik untuk meneliti masalah yang berhubungan dengan kebiasaan merokok dan mengkonsumsi kopi pada remaja terhadap kadar hemoglobin di jalan Mejenan gang 3 Mojoroto Kediri.

\section{METODE}

Desain penelitian yang digunakan adalah studi perbandingan (Comparative study) . penelitian dengan cara membandingkan persamaan dan perbedaan sebagai fenomena untuk mencari faktor-faktor apa, atau situasi bagaimana yang menyebabkan timbulnya suatu peristiwa tertentu (Notoatmodjo, 2018). Teknik sampling yang digunakan purposive sampling yaitu pada populasi remaja di Jalan Mejenan gang 3 Mojoroto Kediri. Sampel yang digunakan dalam penelitian ini adalah darah kapliler remaja perokok dan pengkonsumsi kopi di jalan Mejenan gang 3 Mojoroto Kediri sebanyak 40 remaja.

Sampel pada penelitian ini yaitu remaja yang perokok tidak pengkonsumsi kopi dan pengkonsumsi kopi yang tidak merokok. Remaja yang berusia 18-21 tahun, yang mengkonsumsi kopi setiap hari $\geq 3$ gelas dalam satu hari, dan Merokok setiap hari $\geq 5$ batang dalam satu hari.

\section{HASIL DAN PEMBAHASAN}

Setelah dilakukan pemeriksaan Hemoglobin metode POCT pada darah kapiler remaja perokok dan pengkonsumsi kopi di jalan Mejenan gang 3 Mojoroto Kediri, didapatkan hasil pada Tabel 1 dan Tabel 2. Dari data sekunder dilakukan uji tabulasi silang antara rokok dan kopi terhadap kadar hemoglobin pada remaja di Jalan Mejenan gang 3 Mojoroto 
Kediri. Uji ini digunakan untuk mengetahui pengaruh rokok dan kopi terhadap kadar hemoglobin pada remaja perokok dan pengkonsumsi kopi di jalan Mejenan gang 3 Mojoroto Kediri. Uji ini digunakan untuk mengetahui pengaruh rokok dan kopi terhadap kadar hemoglobin pada remaja perokok dan pengkonsumsi kopi di Jalan Mejenan gang 3 Mojoroto Kediri, yang di dapatkan hasil dengan hasil pada Tabel 3 dan Tabel 4, dan Gambar 1.

Pada penelitian ini, responden dengan kadar hemoglobin normal pada perokok mendapatkan kadar rerata hemoglobin 14,5 g/dL sedangkan responden dengan kadar hemoglobin tinggi memiliki rerata hemoglobin $17,67 \mathrm{~g} / \mathrm{dL}$ dan responden dengan kadar hemoglobin rendah memiliki rerata hemoglobin $11,62 \mathrm{~g} / \mathrm{dL}$. Hal ini serupa dengan penelitian yang dilakukan oleh Leifert (2008) yaitu peningkatan kadar hemoglobin pada perokok yang disebabkan oleh paparan terhadap karbon monoksida (CO) yang merupakan salah satu komponen rokok.

Penelitian yang serupa lainnya yaitu dilakukan oleh Amelia et al. (2016) terdapat 65 orang pendonor darah di Palang Merah Indonesia cabang Padang, menemukan bahwa tidak terdapat hubungan bermakna antara derajat merokok dengan hemoglobin. Penelitian oleh Susiyati (2007) mengenai hubungan kebiasaan merokok dan kadar hemoglobin dengan kesegaran jasmani yang dilakukan pada siswa Sekolah Menengah Kejuruan (SMK) juga menunjukkan tidak adanya hubungan bermakna antara lama merokok dengan jumlah rokok yang dikonsumsi perhari dengan kadar hemoglobin.

Hasil penelitian ini tidak selaras dengan yang dilakukan oleh Shah et al (2012) yang mendapatkan kadar hemoglobin pada perokok lebih tinggi jika dibandingkan dengan non perokok. Pada penelitian yang dilakukan oleh Bashir et al. (2016) dilaporkan juga peningkatan kadar hemoglobin yang berkorelasi dengan peningkatan ukuran eritrosit

Pada perokok jika dibandingkan dengan bukan perokok. terdapat beberapa faktor yang mempengaruhi kadar hemoglobin pada tiap individu yaitu usia, jenis kelamin, asupan gizi, aktivitas fisik, ketinggian daerah tempat tinggal, kebiasaan lamanya menghisap rokok, obat-obatan yang dikonsumsi, serta alat dan metode tes yang digunakan. Peneliti tidak meninjau lebih lanjut mengenai beberapa faktor yang dapat mempengaruhi kadar hemoglobin seperti asupan gizi, derajat aktivitas fisik, ketinggian daerah tempat tinggal, yang dapat berdampak pada nilai dari kadar hemoglobin responden.

Penelitian ini menggunakan data primer berupa kuesioner untuk mendapatkan data konsumsi rokok dan pemeriksaan darah kapiler untuk melihat kadar hemoglobin. Data yang didapatkan dari kuesioner juga tergantung dari kejujuran responden serta pemahaman responden terhadap pertanyaan yang diajukan.Selain itu terbatasnya jumlah responden yang memenuhi kriteria inklusi dan eksklusi juga mungkin berpengaruh terhadap hasil penelitian.
Pada hasil pengkonsumsi kopi, Pada 20 responden di data umum didapatkan sebanyak 1 remaja berumur 18 tahun, 6 remaja berumur 19 tahun, 7 remaja berumur 20 tahun, dan 6 remaja berumur 21 tahun. Menurut Thalib (2010) (usia 1821) merupakan remaja akhir dan sesuai dengan kriteria inklusi yang dibuat oleh peneliti. Pada data khusus dapat dilihat pada Tabel 2 menunjukkan adanya responden yang mengalami penurunan hemoglobin sebanyak 3 responden $(15,0 \%)$ mengalami penurunan hemoglobin sekitar $11,2 \mathrm{~g} / \mathrm{dL}$, $9,2 \mathrm{~g} / \mathrm{dL}$ dan $11,7 \mathrm{~g} / \mathrm{dL}$. Sedangkan sebanyak 2 responden $(10,0 \%)$ mengalami peningkatan hemoglobin sekitar 15,0 $\mathrm{g} / \mathrm{dL}$ dan $15,6 \mathrm{~g} / \mathrm{dL}$. Dan sebanyak 15 responden $(75,0 \%)$ masih dalam keadaan normal sekitar rerata 13,2 g/dL.

Kopi yang diminum oleh responden bisa mencapai dosis kopi yang telah ditentukan dosis yang diizinkan 100-200 mg/hari. Menurut Apinino (2014) semakin banyak mengkonsumsi kopi lebih dari 6 cangkir sehari dapat menyebabkan beberapa penyakit seperti kolesterol darah, homosistein serum dan tekanan darah yang dapat menjadi faktor resiko meningkatnya penyakit jantung coroner.

Dari hasil penelitian didapatkan bahwa responden mempunyai kadar hemoglobin dalam batas normal dengan frekuensi minum kopi 1-6 cangkir perhari. Sedangkan pada responden kadar hemoglobin yang rendah memiliki pola yang tidak sehat akibat dari kebiasaan merokok, begadang, dan pola makanan serta frekuensi minum kopi yang melebihi batas normal yakni $>6$ cangkir perhari.

Pada hasil penelitian ini menunjukkan bahwa kopi tidak mengubah kadar hemoglobin pada remaja di jalan Mejenan gang 3 Mojoroto Kediri. Hal ini dikarenakan sebagian besar responden mempunyai kebiasaan mengkonsumsi kopi masih dalam batas normal yakni 1-6 cangkir perhari, serta kebiasaan yang baik seperti istirahat yang cukup, mengkonsumsi makanan yang bergizi sebagiamana pola hidup yang sehat mempunyai peranan penting untuk mempertahankan kebugaran jasmani seseorang. Sedangkan pada responden dengan kadar hemoglobin rendah memiliki kebiasaan mengkonsumsi kopi $>6$ cangkir perhari, sehingga melebihi dosis yang dianjurkan, istirahat yang $<8$ jam, dan mempunyai kebiasaan yang kurang baik seperti merokok, makanan instan dan siap saji.

\section{KESIMPULAN}

Kadar hemoglobin pada perokok yang tidak normal sebanyak 10 remaja (50\%) sedangkan kadar hemoglobin normal sebanyak 10 remaja (50\%). Kadar hemoglobin pada pengkonsumsi kopi yang tidak normal sebanyak 5 remaja (25\%) sedangkan kadar hemoglobin normal sebanyak 15 remaja (75\%). Perbandingan kadar hemoglobin pada kebiasaan merokok dan konsumsi kopi yang lebih memepengaruhi yaitu pada perokok dengan jumlah remaja sebanyak 50\% yang tidak normal dan pada kopi kadar hemoglobin yang tidak normal $25 \%$. 
TABEL 1. hasil Gambaran Pemeriksaan Hemoglobin Pada Darah Kapiler Remaja Perokok Di Jalan Mejenan Gang 3 Mojoroto Kediri

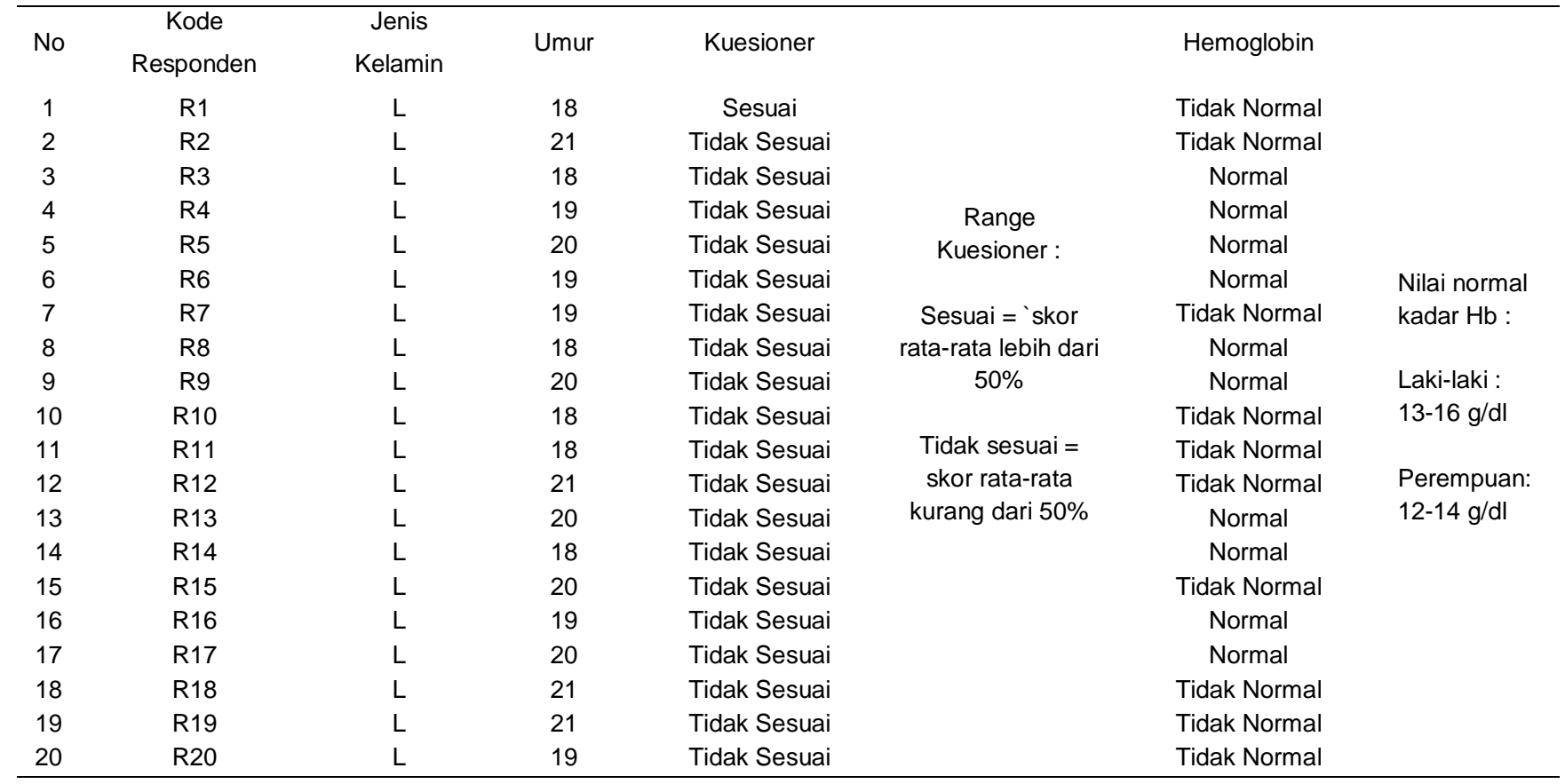

TABEL 2. Hasil Gambaran Pemeriksaan Hemoglobin Pada Darah Kapiler Remaja Pengkonsumsi Kopi Di Jalan Mejenan Gang 3 Mojoroto Kediri

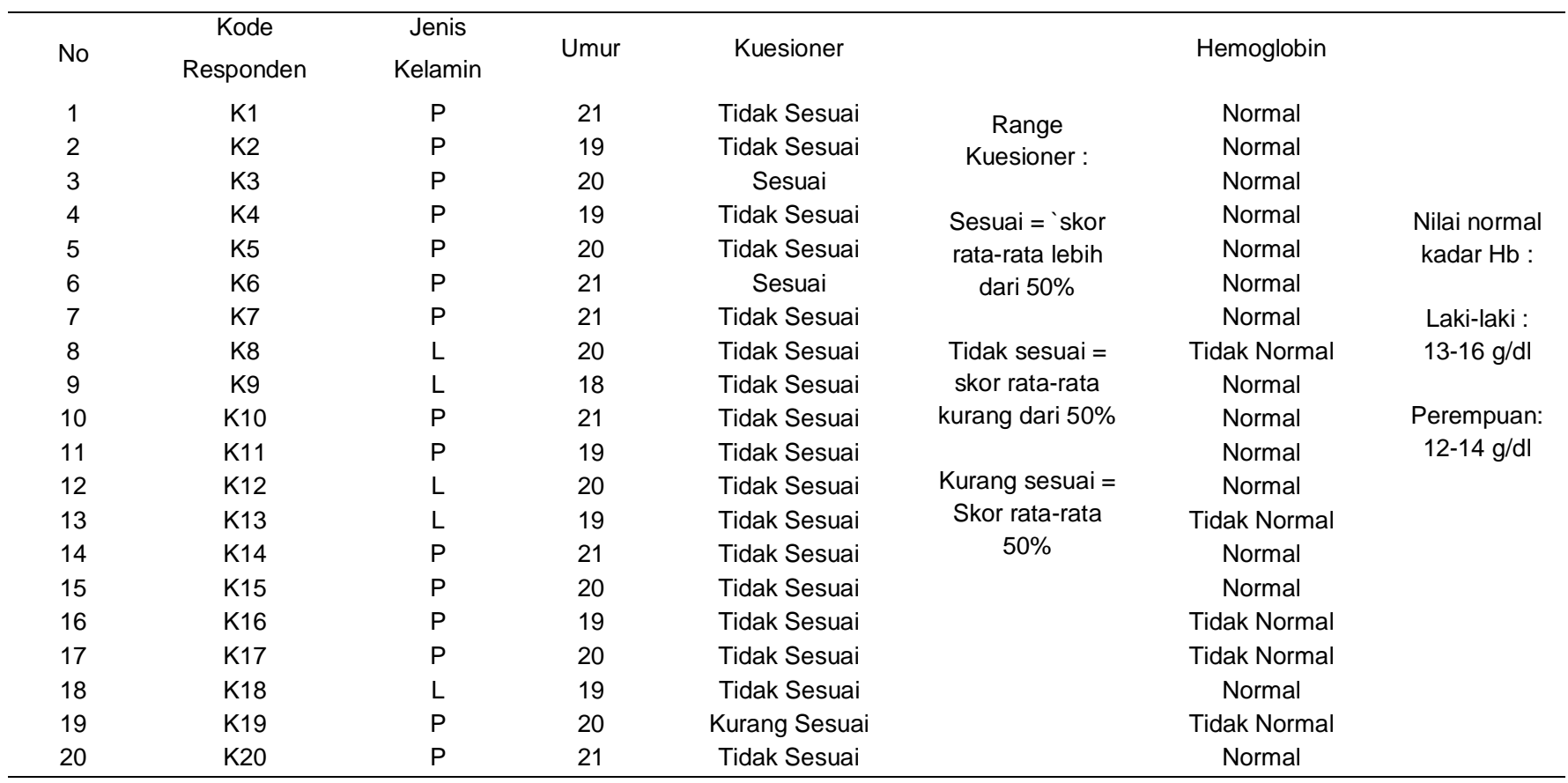

TABEL 3. Hasil Perbandingan Pengaruh Rokok Terhadap Kadar Hemoglobin Pada Remaja Di Jalan Mejenan Gang 3 Mojoroto Kediri

\begin{tabular}{|c|c|c|c|c|}
\hline \multirow[b]{3}{*}{ Kuesioner Rokok } & \multicolumn{4}{|c|}{ Hemoglobin } \\
\hline & & Normal & Tidak Normal & $p$-value \\
\hline & $\begin{array}{c}\text { Sesuai } \\
\text { Tidak Sesuai }\end{array}$ & $\begin{array}{c}0(0,0 \%) \\
10(50,0 \%) \\
10(50,0 \%)\end{array}$ & $\begin{array}{c}1(5,0 \%) \\
9(45,0 \%) \\
10(50,0 \%)\end{array}$ & 0,423 \\
\hline
\end{tabular}


TABEL 4. Hasil Perbandingan Pengaruh Kopi Terhadap Kadar Hemoglobin Pada Remaja Di Jalan Mejenan Gang 3 Mojoroto Kediri

\begin{tabular}{ccccc}
\hline & & \multicolumn{2}{c}{ Hemoglobin } & \multirow{2}{*}{ N-value } \\
& & Normal & Tidak Normal & \\
\multirow{4}{*}{ Kuesioner Kopi } & $2(10,0 \%)$ & $0(0,0 \%)$ & \\
& Sesuai & $13(65,0 \%)$ & $4(20,0 \%)$ & 0,423 \\
& Tidak Sesuai & $0(0,0 \%)$ & $1(5,0 \%)$ & \\
\hline & Kurang Sesuai & $15(75,0 \%)$ & $5(25,0 \%)$ & \\
\hline
\end{tabular}

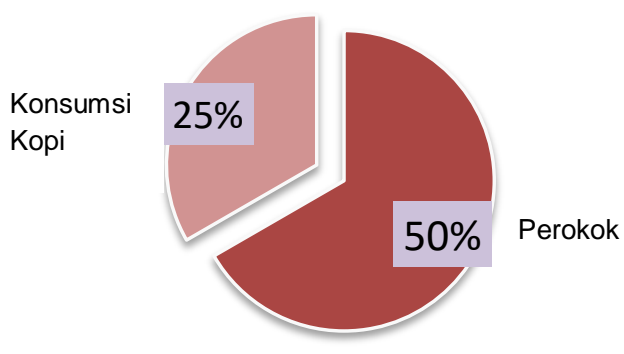

GAMBAR 1. Diagram Persentase Hasil Tidak Normal Pemeriksaan Hemoglobin Perokok Dan Pengkonsumsi Kopi

\section{KONTRIBUSI PENULIS}

Adapun kontribusi penulis baik penulis utama, kedua, dan ketiga berperan dalam penelitian dan pembuatan karya ilmiah dan jurnal ilmiah.

\section{PENDANAAN}

Sumber pendanaan mandiri dari penulis

\section{UCAPAN TERIMA KASIH}

Kepada semua yang telah membantu dalam penelitian ini kami sampaikan terimakasih.

\section{REFERENSI}

Amelia, R., Nasrul, E., \& Basyar, M. (2016). Hubungan Derajat Merokok Berdasarkan Indeks Brinkman dengan Kadar Hemoglobin. Jurnal Kesehatan Andalas, 5(3), 619-624. doi: 10.25077/jka.v5i3.587

Ajiwibawani, P. (2015). Pengaruh Faktor Internal dan Eksternal Gaya Hidup terhadap Keputusan Pembelian (Studi pada Konsumen D'goda Coffe Pazkul Sidoarjo). Skripsi. Universitas Negeri Surabaya.

Apinino, R. (2014). Batas konsumsi kopi dalam sehari. Jakarta: PT Rajagrafindo.

Bashir, B. A., Gibreel, M. O., Abdalatif, H. M., Mohamed, M. A., Ahmed, E. A., Mohamed, M. S., \& Hamid. K. A. (2016). Impact of tobacco cigarette smoking on hematologic parameters among male subjects in Port Sudan Ahlia College, Sudan. Sch J App Med Sci, 4(4A), 1124-1128. Retrieved from http://saspublisher.com/wp-content/uploads/2016/05/SJAMS-44A1124-1128.pdf

Hoffbrand, A. V., Petit, J. E., \& Moss, P. A. H. (2012). Kapita Selekta
Hematologi. Edisi 4. Jakarta: EGC.

Leifert, J. A. (2008). Anemia and Cigarette Smoking. Int J Lab Hematol, 30(3), 177-84. doi: 10.1111/j.1751-553X.2008.01067.x.

Murray, R. K., Bender, D. A., \& Botham, K. M. (2014). Biokimia Harper. Edisi 29. Jakarta: EGC.

Riskesdas. (2007). Laporan Hasil Riskesdas Provinsi Sulut Tahun 2007. Jakarta: Badan Penelitian dan Pengembangan Kesehatan.

Riswanto. (2013). Pemeriksaan Hematologi Selayang Pandang. Jakarta: Alfamedia Kanal Medika.

Shah, B. K., Nepal, A. K., Agrawal, M., \& Sinha, A. K. (2012). The effect of cigarette smoking on hemoglobin levels compared between smokers and non smokers. Sunsari Techncal Collage Journal, 1(1), 42-44. doi: 10.3126/stcj.v1i1.7985.

Susiyati, E. (2007). Hubungan Kebiasaan Merokok dan Kadar Hemoglobin dengan Kesegaran Jasmani Siswa Putra Sekolah Menengah Kejuruan (Studi di SMK Muhammadiyah 1 Surakarta). Skripsi. Universitas Diponegoro. Semarang.

Thalib, S. B. (2010). Psikologi Pendidikan Berbasis Analisis Empiris Aplikatif. Jakarta: Kencana Prenada Media Group.

WHO. (2016). Call For Nomination Of Experts To Serve On The Strategic Advisory Group Of Experts On Immunization (SAGE) Working Group On Typhoid Vaccines. Baltimore: World Health Organization. Retrieved from https://www.coalitionagainsttyphoid.org/call-for-nomination-of-experts-toserve-on-the-strategic-advisory-group-of-experts-on-immunization-sageworking-group-on-typhoid-vaccines/.

Wibowo, D. V., Pangemanan, D. H. C., \& Polii, H. (2017). Hubungan Merokok dengan Kadar Hemoglobin dan Trombosit pada Perokok Dewasa. Jurnal eBiomedik (eBm), 5(2), 1-6. doi: 10.35790/ebm.v5i2.18510.

Conflict of Interest Statement: The authors declare that the research was conducted in the absence of any commercial or financial relationships that could be construed as a potential conflict of interest.

Copyright $\odot 2021$ Purdanianti, Ermawati, and Berlian. This is an open-access article distributed under the terms of the Creative Commons Attribution License (CC BY). The use, distribution or reproduction in other forums is permitted, provided the original author(s) and the copyright owner(s) are credited and that the original publication in this jour- nal is cited, in accordance with accepted academic practice. No use, distribution or reproduction is permitted which does not comply with these terms. 